\title{
Relationship Between Bone Mineral Density and Disease Activity in Patients with Ankylosing Spondylitis
}

\author{
Ankilozan Spondilitli Hastalarda Kemik Mineral Yoğunluğunun \\ Hastalık Şiddeti ile ilişkisi
}

\author{
Hasan Ulusoy ${ }^{1}$, Ayhan Bilgici², Ömer Kuru², Nebahat Sarıca ${ }^{1}$, Şule Arslan ${ }^{1}$, Ünal Erkorkmaz \\ ${ }^{1}$ Gaziosmanpaşa Üniversitesi Tıp Fakültesi, Fiziksel Tıp ve Rehabilitasyon Anabilim Dalı, Tokat, Turkey \\ 20ndokuz Mayıs Üniversitesi Tıp Fakültesi, Fiziksel Tıp ve Rehabilitasyon Anabilim Dalı, Samsun, Turkey \\ ${ }^{3}$ Gaziosmanpaşa Üniversitesi Tıp Fakültesi, Biyoistatistik Anabilim Dalı, Tokat, Turkey
}

\section{Abstract}

Objective: This retrospective study was planned to determine the relationship between bone mineral density (BMD) and clinical, radiological and laboratory parameters in patients with ankylosing spondylitis (AS).

Materials and Methods: The study group consisted of 28 patients with a mean disease duration of $11.9 \pm 6.1$ years. In addition to clinical and demographic variables, lumbar and femoral BMD were evaluated with dual energy X-ray absorbtiometry. Lumbar spine score (LSS) and sacroiliac score (SIS) were calculated by grading of standard radiographs. Erythrocyte sedimentation rate (ESR) and C-reactive protein (CRP) level were determined as laboratory parameters.

Results: The rate of osteoporosis and osteopenia were $7.1 \%$ and $25 \%$ at the lumbar spine, and $14.2 \%$ and $17.8 \%$ at the femoral neck, respectively. LSS was significantly correlated with lumbar BMD $(r=0.70, p<0.001)$, but not with femoral neck BMD $(r=-0.11$, $p=0.55)$. SIS was negatively correlated with femoral neck BMD $(r=-0.79, p<0.001)$, but not correlated with lumbar BMD $(r=0.19$, $p=0.32$ ). While lumbar BMD was positively correlated with disease duration $(r=0.37, p=0.05)$, femoral neck BMD showed negative correlation with disease duration $(r=-0.46, p=0.01)$. The evaluation of clinical paramaters and BMD showed that morning stiffness, spinal pain, ESR and CRP were not correlated with BMD. Only modified Schober's test was related to BMD on both lumbar spine and femoral neck.

Conclusion: Ankylosing spondylitis patients are at risk for developing osteoporosis. In advanced disease, the lumbar BMD is misleadingly high because of paravertebral calcification and ossification. Therefore, it is more rational to evaluate the BMD at the femoral neck. (Turk J Rheumatol 2010; 25: 24-8)

Key words: Ankylosing spondylitis, osteoporosis, bone mineral density

Received: 31.08 .2008

Accepted: 13.11 .2008
Özet

Amaç: Bu retrospektif çalıșma ankilozan spondilitli hastalarda (AS) lomber vertebra ve femur boynunda kemik mineral yoğunluğunu (KMY) belirlemek, KMY ile klinik, radyolojik ve laboratuvar parametreler arasındaki ilișkiyi değerlendirmek amacıyla planlanmıștır. Yöntem ve Gereçler: Çalıșma grubu, ortalama hastalık süresi $11.9 \pm 6.1$ yıl olan 28 AS hastasından olușmuștur. Klinik ve demografik değișkenlere ilave olarak dual energy X-ray absorbtiometry (DEXA) ile belirlenmiș lomber bölge ve femur boyun KMY değerleri kaydedildi. Lomber spinal skor (LSS) ve sakroiliyak skor (SIS) standard radyografiler kullanılarak hesaplandı. Eritrosit sedimentasyon hızı (ESH) ve C-reaktif protein düzeyleri laboratuvar parametreler olarak belirlendi.

Bulgular: Osteoporoz ve osteopeni sıklığı sırasıyla lomber bölgede $\% 7.1$ ve $\% 25$, femur boynunda $\% 14.2$ ve $\% 17.8$ olarak bulundu. LSS lomber KMY ile pozitif korelasyon gösterirken $(r=0.70, p<0.001)$, femur boyun KMY ile korelasyon göstermemiștir $(r=-0.11, p=0.55)$. SIS ile femur boyun KMY arasında negatif korelasyon bulunurken $(r=-0.79, p<0.001$, SIS ile lomber KMY arasında korelasyon bulunamamıștır $(r=0.19, p=0.32)$. Hastalık süresi lomber KMY ile pozitif korelasyon ( $r=0.37, p=0.05)$, femur boyun KMY ile negatif korelasyon göstermiștir $(r=-0.46, p=0.01)$. Klinik ve laboratuvar parametreler değerlendirildiğinde sabah tutukluğu, spinal ağrı, ESH ve CRP'nin KMY ile ilișkili olmadığı, yalnızca modifiye Schober testinin hem lomber hem de femur boyun KMY ile ilișkili olduğu görülmüștür.

Sonuç: Ankilozan spondilit hastaları osteoporoz gelișim riski tașımaktadır. Illerlemiș hastalıkta lomber KMY değerleri paravertebral ossifikasyon ve kalsifikasyonlar nedeniyle yanıltıcı olarak yüksek bulunmaktadır. Bu nedenle, ilerlemis AS hastalarında kemik kütle kaybının femur boyun bölgesinden değerlendirilmesi daha akılcı görünmektedir.

(Turk J Rheumatol 2010; 25: 24-8)

Anahtar sözcükler: Ankilozan spondilit, osteoporoz, kemik mineral yoğunluğu

Alındığı Tarih: 31.08.2008 Kabul Tarihi: 13.11.2008

This research was presented as abstract on Third National Rheumatic Diseases Congress, 14-18 may 2008, Antalya, Turkey

Address for Correspondence: Dr. Hasan Ulusoy, Gaziosmanpaşa Üniversitesi Tıp Fakültesi, Fiziksel Tıp ve Rehabilitasyon Anabilim Dalı, Tokat, Turkey Phone: +90424 2478928 E-mail: ulusoyh@mynet.com 


\section{Introduction}

Ankylosing spondylitis (AS) is a chronic inflammatory disease which predominantly affects young men. Inflammatory enthesopathy progressing to ossification and ankylosis is the pathologic basis of the disease (1). A considerable decrease in bone mineral density at lumbar spine and femoral neck has been observed in AS (2). Osteoporotic vertebral fracture rates have ranged from $0 \%$ to $18 \%$ (3). In patients with early $A S$, dual energy X-ray absorptiometry (DEXA) method shows bone loss at the lumbar spine, but in advanced disease, syndesmophytes and facet joint ankylosis at the lumbar spine may mask the bone mass. Some researches reported a correlation between femoral neck BMD evaluated with DEXA and disease duration in AS $(4,5)$. Osteoporosis in patients with AS is probably a multifactorial condition related to genetic factors, inflammation, adverse effects of medications, silent bowel disease, and gradual decrease in spinal mobility caused by worsening ankylosis. There are a few data on the benefit of anti-tumor necrosis factor-alpha and biphosphonate therapy on BMD in AS $(6,7)$. The aim of this study was to determine BMD of the lumbar spine and femoral neck in a group of Turkish patients with AS and to evaluate the relationship between BMD and clinical parameters, radiological parameters, laboratory parameters.

\section{Materials and Methods}

In this retrospective study, twenty-eight patients who fulfilled the modified New York criteria for AS were enrolled (8). Medical records were reviewed and patients with a history of medication use known to affect bone metabolism were excluded. Spinal pain was assessed using a $100 \mathrm{~mm}$ visual analog scale. Other parameters were duration of morning stiffness, modified Schober's test, erythrocyte sedimentation rate (ESR) and C-reactive protein (CRP) level. An anteroposterior radiograph of the pelvis and anteroposterior and lateral radiographs of the lumbar spine were taken in all patients. For assessment of sacroiliitis, radiographs of the pelvis were scored on a 5-point scale to obtain a sacroiliac score (SIS) (8). To obtain a lateral spine score (LSS), anterior and posterior margins of each intervertebral space from L1-L2 to L4-L5 were scored as followed: $0=$ no syndesmophytes, $1=$ nonbridging syndesmophytes, 2=bridging syndesmophytes (9). Since Bath AS Radiology Index hardly changes with each additional syndesmofite, we did not prefer it (10). Instead, we used a specific scoring method with regard to posteroanterior DEXA scan, that is, L2-L4 vertebral levels (11).
Although we did not score the zygapophyseal joints separately, it is well established that zygapophyseal joint involvement and the presence of syndesmophytes in AS are well correlated (12). All radiographs were assessed and scored by the same investigator (AB). LSS and SIS were taken as radiologic indicators of disease severity. Vertebral fractures were defined by a visual semiquantitative grading system as a reduction of more than $20 \%$ in anterior, middle, and/or posterior height (13). Lumbar BMD (L2-L4) and left femoral neck were measured by DEXA (Norland). According to World Health Organization criteria, osteopenia was defined as a T score $<-1$, and osteoporosis as a T score $\leq-2.5$ (14).

Continuous variables were presented as the mean \pm standart deviation. Pearson's correlation coefficients were calculated to test for associations of the BMD measurements, demographic variables, clinical parameters, laboratory results, and radiological scores. A p-value $<0.05$ was considered statistically significant. Analyses were performed using a commercial software.

\section{Results}

There were 21 (75\%) men and 7 (25\%) women in the study group. The mean age of study group was $37.4 \pm 11.1$ years. The mean disease duration was $11.9 \pm 6.1$ years. Twenty-two (78.6\%) patients were HLA-B27-positive. The current medications used by the patients were nonsteroidal antiinflammatory drugs $(n=24)$, sulfasalazine $(n=22)$, methotrexate $(n=5)$ and etanercept $(n=1)$. Peripheral joint involvement was present in 6 patients. Clinical, laboratory and radiological characteristics of the study group are shown in Table 1. The lumbar BMD measurements showed that $25 \%$ of patients had osteopenia, $7.1 \%$ were osteoporotic, whereas by femoral neck BMD measurements $17.8 \%$ hadosteopenia and $14.2 \%$ had osteoporosis. Only one (3.5\%) patient had lumbar vertabral fracture at $L 1$ vertebra.

Lateral lumbar radiographs showed syndesmophytes in $21(75 \%)$ patients. LSS was positively correlated with age $(r=0.45, p=0.015)$ and disease duration $(r=0.45$, $p=0.013$ ). Additionally, LSS was negatively correlated with modified Schober's test $(r=-0.52, p=0.004)$. SIS was not related to age, disease duration or modified Schober's test. LSS was significantly correlated with BMD of lumbar spine $(r=0.70, p<0,001)$, but not with femoral neck BMD $(r=-0.11, p=0.55)$. SIS was not correlated with lumbar spine BMD ( $r=0.19, p=0.32)$, but negatively correlated with femoral neck BMD $(r=-0.79, p<0.001)$. While lumbar BMD was positively correlated with disease duration $(r=0.37, p=0.05)$, femoral neck BMD was negatively cor- 
related with disease duration $(r=-0.46, p=0.01)$. Age was not related to BMD measurements at any sites. Modified Schober's test was related to lumbar BMD $(r=-0.38$, $p=0,04)$ and femoral neck BMD $(r=0.43, p=0.02)$. On the other hand, morning stiffness, spinal pain, ESR and CRP were not related to BMD (Table 2).

\section{Discussion}

This study confirms that lumbar BMD measurement is influenced by radiologic progression of AS. LSS was positively correlated with lumbar BMD, but not with femoral neck BMD. Additionally, SIS was negatively correlated with femoral neck BMD, but not with lumbar spine BMD. Disease duration and modified Schober's test were related to BMD at both the lumbar spine and femoral neck. However, there was no relationship between BMD and pain, morning stiffness, ESR or CRP.

Table 1. Clinical, laboratory and radiological characteristics of patients with ankylosing spondylitis

\begin{tabular}{lcc}
\hline & Mean \pm SD & Min-Max \\
\hline Age, years & $37.4 \pm 11.1$ & $19-68$ \\
Disease duration, years & $11.9 \pm 6.1$ & $3-30$ \\
Morning stiffness, min & $39.1 \pm 36.8$ & $0-120$ \\
Spinal pain, 100 mm VAS & $38 \pm 23$ & $0-80$ \\
Modified Schober test, cm & $2.1 \pm 1.4$ & $1-5$ \\
CRP level, mg/l & $13.4 \pm 10.6$ & $3-48$ \\
ESR, mm/h & $27.7 \pm 17.0$ & $6-74$ \\
Sacroiliac score (0-8) & $6.2 \pm 1.7$ & $4-8$ \\
Lateral spine score (0-8) & $4.1 \pm 3.0$ & $0-8$ \\
\hline
\end{tabular}

SD: Standard deviation, VAS: Visual analog scale, CRP: C-reactive protein, ESR: Erythrocyte sedimentation rate, ,Min-Max: Minimum-Maximum

Table 2. Pearson correlation coefficients for BMD values versus other parameters

\begin{tabular}{lcccc}
\hline Variables & $\begin{array}{c}\text { Lomber } \\
\text { spine BMD } \\
\left(\mathbf{g} / \mathbf{c m}^{2}\right)\end{array}$ & $\begin{array}{c}\text { Lomber T } \\
\text { score }\end{array}$ & $\begin{array}{c}\text { Femoral } \\
\text { neck BMD } \\
\left(\mathbf{g} / \mathbf{c m}^{2}\right)\end{array}$ & $\begin{array}{c}\text { Femoral } \\
\text { T score }\end{array}$ \\
\hline LSS & $0.708^{*}$ & $0.740^{*}$ & -0.118 & -0.060 \\
SIS & 0.195 & 0.154 & $-0.795^{*}$ & $-0.642^{*}$ \\
Age & 0.323 & 0.296 & -0.194 & -0.149 \\
Disease duration & $0.374^{*}$ & $0.420^{*}$ & $-0.461^{*}$ & $-0.452^{*}$ \\
Modified Schober's & $-0.385^{*}$ & -0.304 & $0.438^{*}$ & $0.434^{*}$ \\
Spinal pain & -0.046 & -0.079 & -0.046 & -0.058 \\
Morning stiffness & -0.222 & -0.244 & 0.304 & 0.340 \\
ESR & 0.146 & 0.150 & -0.080 & -0.025 \\
CRP & 0.132 & 0.152 & -0.011 & -0.069 \\
\hline
\end{tabular}

BMD: Bone mineral density, LSS: Lateral spinal score, SIS: Sacroiliac score, ESR: Erythrocyte sedimentation rate, CRP: C-reactive protein *Statistically significant correlation $(p<0.05)$
Because low BMD is an independent predictor of fracture risk in normal population there has been a great interest in determining the prevalence and severity of osteopenia in AS (3). Low BMD in AS patients has been reported in the literature. There are different rates for osteoporosis and osteopenia. El Maghraoui et al. (15) reported 18.7\% osteoporosis and $31.2 \%$ osteopenia at the lumbar spine, $13.7 \%$ and $41.2 \%$ at the femoral neck, respectively. An other study revealed $8 \%$ osteoporosis and $18 \%$ osteopenia at the lumbar spine, $6 \%$ and $52 \%$ at the femoral neck, respectively (16). We found that the frequency of osteoporosis and osteopenia for the lumbar spine were $7.1 \%$ and $25 \%$ respectively, whereas for the femoral neck they were $14.2 \%$ and $17.8 \%$ respectively. The vertebral fracture rate in AS is reported to be $0 \%$ to $18 \%$ in Western countries $(3,4,9,17,18)$ and $40.9 \%$ in Turkey $(19)$. In our study, there was only one patient with fracture $(3.5 \%)$. This may be explained by the shorter mean disease duration $(11.9 \pm 6.1$ years) of our patients. Baek et al. (20) also reported a vertebral fracture rate of $3.9 \%$.

Posteroanterior DEXA has generally been used to measure BMD of the spine and hip in AS patients. In mild $A S$, lumbar spine and femoral neck BMD have been found to be lower in patients than controls. In severe AS, femoral neck BMD is decreased compared with controls but lumbar spine BMD is not, and in some instances, even increased. Although mild and severe diseases were defined according to various criteria, it seems likely that syndesmophyte formation, facet joint fusion and ligament ossification explain the observed discrepancy in lumbar spine and femoral neck BMD in patients with severe diseases $(4,19,21,22)$. In this study, we found that LSS was positively correlated with lumbar spine BMD. This finding indicates that the presence of syndesmophytes may influence posteroanterior lumbar DEXA results and give rise to falsely increased BMD. However, we did not found a correlation between LSS and femoral neck BMD. Because of this, femoral neck BMD measurement may be more reliable than lumbar spine BMD in advanced AS $(15,23-25)$. Previous studies have shown that vertebral fracture risk is related to low femoral neck BMD, but not with lumbar spine BMD $(4,18,22)$. Syndesmophyte formation and ligament calcification may have supressed this relationship (18). In our study, we found that SIS was negatively correlated with femoral neck BMD, but not with lumbar spine BMD. This result is consistent with previous findings of Speden et al (16). But, Gilgil et al. (11) reported no relationship between SIS and BMD values at both the lomber spine and femoral neck.

Quantitative computed tomography (QCT) or a lateral projection of the lumbar spine by DEXA reflecting more 
accurate results than posteroanterior lumbar DEXA in determining the bone mass in AS has been suggested $(5,26)$. Lateral lumbar DEXA has the advantage of isolating the body of vertebra from the ankylosed zygapophyseal joints, anterior or posterior syndesmophytes. Therefore, lateral lumbar DEXA has been found more sensitive to determine lumbar spine BMD than posteroanterior lumbar DEXA. In addition, kyphotic patients can undergo an easier procedure $(11,26,27)$. Bone mass loss determined by lateral lumbar DEXA has been found positively correlated with bone mass loss determined by femoral neck DEXA (26). QCT has the advantage of isolating the trabecular bone of vertebra from the cortical bone, ankylosed zygapophyseal joints and syndesmophytes. Because of this, QCT has been found more reliable than DEXA, especially in advanced AS. Indeed, QCT confirms spinal bone loss that is proportional to the duration of the disease $(5,25)$. In patients with syndesmophytes and long disease duration ( $>10$ years), no case of osteoporosis had been identified by DEXA at the lumbar spine. When QCT at the lumbar spine and DEXA at the femoral neck were used to measure BMD, osteoporosis frequency had been found $31 \%$ and $21 \%$ respectively. Significant positive correlation between QCT results at the lumbar spine and DEXA results at the femoral neck had been reported in the same study (25). Lange et al. (2) showed bone mass loss by QCT at the lumbar spine in both early and late AS patients. Nevertheless, lateral lumbar DEXA may be more suitable for serial BMD measurements because it has lower radiation dose than QCT.

A significant positive correlation between disease duration and lumbar spine BMD has been reported $(4,23$, $24,28,29)$. This could be due to the presence of syndesmophytes in patients with chronic disease. We also found significant positive correlation between disease duration and lumbar spine BMD. Moreover, we found that bone loss of the femoral neck was proportional to disease duration, in keeping with previous reports $(4,24,28,30)$. Some investigators reported no significant correlation between disease duration and BMD at both the lumbar spine and femoral neck $(18,28,30,31)$.

We found positive correlation between modified Schober's test and lumbar spine BMD, and negative correlation with femoral neck BMD as reported in some earlier studies $(4,5)$. The correlation between lumbar spine BMD and Schober's test presumably reflects the changes in DEXA and spinal mobility induced by syndesmophyte formation. However, other investigators did not found significantly increased bone mass at the lumbar spine in AS patients who had decreased Schober's test $(11,20)$.

Osteopenia in AS is generally considered to be caused by the immobilization associated with spinal ankylosis.
However, it has been reported that bone mass loss frequently occurs in patients with early or mild AS who show little clinical or radiographic evidence of spinal disease (28). Some investigators found a negative correlation between inflammatory markers of disease activity (ESR, CRP, IL6) and BMD (22, 32-34). However, we failed to identify relationship between BMD measurements and ESR or CRP, consistent with earlier data $(5,16,25,35)$. The lack of consistent correlation between ESR, CRP, and BMD may be due to these variables reflecting different time courses. ESR and CRP measure the current status of inflammation, whereas BMD is a longitudinal variable $(16,27)$.

In conclusion, AS patients have an increased risk for developing bone loss. In long standing and radiologically advanced AS, lumbar spine BMD is misleadingly high because of paravertebral calcification and ossification, and the measured value is higher than the real values. Therefore, it is more rational to determine bone loss at femoral neck.

\section{Conflict of Interest}

No conflict of interest is declared by the authors.

\section{References}

1. Sieper J, Braun J, Rudwaleit M, Bonen A, Zink A. Ankylosing spondylitis: an overview. Ann Rheum Dis 2002; 61(Suppl III): 8-18.

2. Lange $U$, Kluge A, Strunk J. Ankylosing spondylitis and bone mineral density-what is the ideal tool for measurement. Rheumatol Int 2005; 26: 115-20.

3. El Maghraoui A. Osteoporosis and ankylosing spondylitis. Joint Bone Spine 2004; 71: 291-5.

4. Donnelly S, Doyle DV, Denton A, Rolfe I, McCloskey EV, Spector TD. Bone mineral density and vertebral compression fracture rates in ankylosing spondylitis. Ann Rheum Dis 1994; 53: 117-21.

5. Lee YS, Schlotzhauer T, Ott SM, van Vollenhoven RF, Hunter J, Shapiro J, et al. Skeletal status of men with early and late ankylosing spondylitis. Am J Med 1997; 103: 203-41.

6. Maksymovych WP, Jhangri GS, Leclercq S, Skeith K, Yan A, Russell AS. An open study of pamidronate in the treatment of refractory ankylosing spondylitis. J Rheumatol 1998; 25: 714-7.

7. Allali F, Breban M, Procher R, Maillefert JF, Dougados M, Roux C. Increase in bone mineral density of patients with spondyloarthropathy treated with anti-tumour necrosis factor. Ann Rheum Dis 2003; 63: 347-9.

8. van der Linden S, Valkenburg HA, Cats A. Evaluation of diagnostic criteria for ankylosing spondylitis. A proposal for modification of the New York criteria. Arthritis Rheum1984; 27: 361-8.

9. Ralston SH, Urquhart GDK, Brzeski M, Sturrock RD. Prevalence of vertebral compression fractures due to osteoporosis in ankylosing spondylitis. BMJ 1990; 300: 563-5.

10. Mackay K, Mack C, Brophy S, Calin A. The Bath Ankylosing Spondylitis Radiology Index (BASRI). Arthritis Rheum 1998; 41: 2263-70. 
11. Gilgil E, Kacar C, Tuncer T, Butun B. The association of syndesmophytes with vertebral bone mineral density in patients with ankylosing spondylitis. J Rheumatol 2005; 32: 292-4.

12. de Vlam K, Mielants $H$, Veys EM. Involvement of the zygapophyseal joints in ankylosing spondylitis: relation to the bridging syndesmophytes. J Rheumatol 1999; 26: 1738-45.

13. Genant HK, Wu CY, van Kuijk C, Nevitt MC. Vertebral fracture assessment using a semiquantitative technique. J Bone Miner Res 1993; 8: 1137-48.

14. Kanis JA, Melton LJ, Christiansen C, Johnston CC, Khaltaev N. The diagnosis of osteoporosis. J Bone Miner Res 1994; 9: 1137-41.

15. El Maghraoui, Borderie D, Cherruau B, Edouard R, Dougados M, Roux C. Osteoporozis, body composition, and bone turnover in ankylosing spondylitis. J Rheumatol 1999; 26: 2205-9.

16. Speden DJ, Calin Al, Ring FJ, Bhalla AK. Bone mineral density, calcaneal ultrasound, and bone turnover markers in women with ankylosing spondylitis. J Rheumatol 2002; 29: 516-21.

17. Raltson SH, Urquhart GDK, Bzeski M, Sturrock RD. Prevalence of vertebral compression fracture rates in ankylosing spondylitis. Br Med J 1990; 300: 563-5.

18. Mitra D, Elvins DM, Speden DJ, Collins AJ. The prevalence of vertebral fractures in mild ankylosing spondylitis and their relationship to bone mineral density. Rheumatology 2000; 39: 85-9.

19. Sivri A, Kilinc S, Gokce-Kutsal Y, Ariyurek M. Bone mineral density in ankylosing spondylitis. Clin Rheumatol 1996; 15: 51-4.

20. Baek HJ, Kang SW, Lee YJ, Shin KC, Lee EB, Yoo CD, et al. Osteopenia in men with mild and severe ankylosing spondylitis. Rheumatol Int 2005; 26: 30-4.

21. Devogelaer JP, Maldague B, Malghem J, Nagant DC. Appendicular and vertebral bone mass in ankylosing spondylitis. A comparison of plain radiographs with single and dual-photon absorbtiometry and with quantitative computed tomography. Arthritis Rheum 1992; 35: 1062-7.

22. Jun JB, Joo KB, Her MY, Kim TH, Bae SC, YooDH, et al. Femoral bone mineral density is associated with vertebral fractures in patients with ankylosing spondylitis: a crosssectional study. J Rheumatol 2006; 33: 1637-41.

23. Meirelles ES, Borelli A, Camargo OP. Influence of disease activity and chronicity on ankylosing spondylitis bone massloss. Clin Rheumatol 1999; 18: 364-8.
24. Capaci K, Hepguler S, Argin M, Tas I. Bone mineral density in mild and advanced ankylosing spondylitis. Yonsei Med J 2003; 44: 379-84.

25. Karberg K, Zochling J, Sieper J, Felsenberg D, Braun J. Bone loss is detected more frequently in patients with ankylosing spondylitis with syndesmophytes. J Rheumatol 2005; 32: 1290-8.

26. Bronson WD, Walker SE, Hillman LS, Keisler LS, Hoyt T, Allen $\mathrm{SH}$. Bone mineral density and biochemical markers of bone metabolism in ankylosing spondylitis. J Rheumatol 1998; 25: 929-35.

27. Mitra D, Elvins DM, Collins AJ. Biochemical markers of bone metabolism in mild ankylosing spondylitis and their relationship with bone mineral density and vertebral fractures. J Rheumatol 1999; 26: 2201-4.

28. Mullaji AB, Upadhyay SS, Ho EK. Bone mineral density in ankylosing spondylitis. DEXA comparison of control subjects with mild and advanced cases. J Bone Joint Surg Br 1994; 76: 660-5.

29. Reid DM, Nicoll JK, Kennedy NSJ, Smith MA, Tothill P, Nuki G. Bone mass in ankylosing spondylitis. J Rheumatol 1986; 13: 932-5.

30. Will R, Palmer R, Bhalla AK, Ring F, Calin A. Osteoporosis in early ankylosing spondylitis: a primary pathological event? Lancet 1989; 23: 1483-5.

31. Juanola X, Mateo L, Nolla JM, Roig-Vilaseca D, Campoy E, Roig-Escofed D. Bone mineral density in women with ankylosing spondylitis. J Rheumatol 2000; 27: 1028-31.

32. Dos Santos FP, Constantin A, Laroche M, Destombes $F$, Bernard J, Mazieres $\mathrm{B}$, et al. Whole body and regional bone mineral density in ankylosing spondylitis. J Rheumatol 2001; 28: 547-9.

33. Maillefert JF, Aho LS, El Maghraoui A, Dougados M, Roux C. Changes in bone density in patients with ankylosing spondylitis: a two-year follow-up study. Osteoporosis Int 2001; 12: 605-9.

34. Gratacos J, Collado A, Pons F, Osaba M, Sanmarti R, Roque $M$, et al. Significant bone mass in patients with early, active ankylosing spondylitis. Arthritis Rheum 1999; 42: 2319-24.

35. Toussirot E, Michel F, Wendling D. Bone density, ultrasound measurements and body composition in early ankylosing spondylitis. Rheumatology Oxford 2001; 40: 882-8. 